POLYMER SCIENCE AND TECHNOLOGY

Volume 20

\title{
POLYMER ALLOYS III
}

Blends, Blocks, Grafts, and

Interpenetrating Networks 


\title{
POLYMER SCIENCE AND TECHNOLOGY
}

\author{
Editorial Board:
}

William J. Balley, University of Maryland, College Park, Maryland J. P. Berry, Rubber and Plastics Research Association of Great Britain, Shawbury, Shrewsbury, England

A. T. DiBenedetto, The University of Connecticut, Storrs, Connecticut C. A. J. Hoeve, Texas A\&M University, College Station, Texas Yöichi Ishida, Osaka University, Toyonaka, Osaka, Japan Frank E. Karasz, University of Massachusetts, Amherst, Massachusetts Osias Solomon, Franklin Institute, Philadelphia, Pennsylvania

\section{Recent volumes in the series:}

Volume 11 POLYMER ALLOYS II: Blends, Blocks, Grafts, and Interpenetrating Networks Edited by Daniel Klempner and Kurt C. Frisch

Volume 12 ADHESION AND ADSORPTION OF POLYMERS (Parts A and B) Edited by Lieng-Huang Lee

Volume 13 ULTRAFILTRATION MEMBRANES AND APPLICATIONS Edited by Anthony R. Cooper

Volume 14 BIOMEDICAL AND DENTAL APPLICATIONS OF POLYMERS Edited by Charles G. Gebelein and Frank F. Koblitz

Volume 15 CONDUCTIVE POLYMERS Edited by Raymond B. Seymour

Volume 16 POLYMERIC SEPARATION MEDIA Edited by Anthony R. Cooper

Volume 17 POLYMER APPLICATIONS OF RENEWABLE-RESOURCE MATERIALS Edited by Charles E. Carraher, Jr. and L. H. Sperling

Volume 18 REACTION INJECTION MOLDING AND FAST POLYMERIZATION REACTIONS Edited by Jiri E. Kresta

Volume 19 COORDINATION POLYMERIZATION Edited by Charles C. Price and Edwin J. Vandenberg

Volume 20 POLYMER ALLOYS III: Blends, Blocks, Grafts, and Interpenetratıng Networks Edited by Daniel Klempner and Kurt C. Frisch

A Continuation Order Plan is avallable for this series A contınuation order will bring delivery of each new volume immediately upon publication Volumes are billed only upon actual shipment For further information please contact the publisher 


\section{POLYMER ALLOYS III}

Blends, Blocks, Grafts, and Interpenetrating Networks

Edited by

Daniel Klempner and Kurt C. Frisch

Polymer Institute

University of Detroit

Detroit, Michigan 


\section{Library of Congress Cataloging in Publication Data}

Symposium on Polymer Alloys 11981: New York, N.Y. Polymer alloys III.

(Polymer science and technology; v. 20)

"Proceedings of a Symposium on Polymer Alloys, sponsored by the Organic Coating and Plastic Division, held August 23-28, 1981, in New York"-T.p. verso.

Includes bibliographical references and index.

1. Polymers and polymerization-Congresses. I. Klempner, Daniel. II. Frisch, Kurt Charles, 1918- . III. American Chemical Society. Division of Organic Coatings and Plastic Chemistry. IV. Title. V. Series.

Proceedings of a Symposium on Polymer Alloys, sponsored by the Organic Coating and Plastic Division, held August 23-28, 1981, in New York

(C) 1983 Plenum Press, New York

Softcover reprint of the hardcover 1st edition 1983

A Division of Plenum Publishing Corporation

233 Spring Street, New York, N.Y. 10013

All rights reserved

No part of this book may be reproduced, stored in a retrieval system, or transmitted in any form or by any means, electronic, mechanical, photocopying, microfilming, recording, or otherwise, without written permission from the Publisher 


\section{PREFACE}

On this, the dawning of a new age in high technology, man is seeking answers to increasingly complex problems. We are routinely launching reusable vehicles into space, designing and building computers with seemingly limitless powers, and developing sophisticated communications systems using laser technology, fiber optics, holography, etc., al1 of which require new and advanced materials. Polymer alloys continue to provide new solutions to the materials problems, and remain an area of ever increasing research.

Polymer alloys are multicomponent macromolecular systems. The components may be all on the same chain (as in block copolymers), on side chains (as in graft copolymers), or in different molecules (as in polyblends and interpenetrating polymer networks). The variety of morphologies possible and the synergistic effects on ultimate properties continue to stimulate research on new polymer alloys. More and more studies on synthesis of new alloys, the kinetics and mechanisms of their formation, and their characterization, are taking place, as well as studies on their processing and applications.

This book presents the proceedings of the Symposium on Polymer Alloys, sponsored by the American Chemical Society's Division of Organic Coatings and Plastics Chemistry held at the 182nd meeting of the American Chemical Society in New York, in August, 1981. The most recent efforts of scientists and engineers from all over the world in this increasingly important field are presented in the following pages. 
We wish to express our appreciation to the authors who contributed to this book, as well as to the University of Detroit for their encouragement.

Danie1 K1empner

Kurt C. Frisch

Polymer Institute

University of Detroit 
CONTENTS

Model Plastic - Rubber Composites from Emulsion

Polymers . . . . . . . . . . . . . . . 1

M. Morton, N.K. Agarwal, and M. Cizmecioglu

On the Correlation of Mechanical Properties of

High Impact Polystyrene with its Morphology,

Molecular-Weight Characteristics and

Extrusion Conditions . . . . . . . . . . . . . .

V.D. Yenalyev, V.I. Melnichenko, O.P. Bovkunenko, A.N. Shelest, N.M. Tchalaya, Y.I. Yegorova, and N.G. Podosyonova

Correlation of Morphology, Mechanical Properties

and Processing Conditions of Modified

High Impact Polystyrene . . . . . . . . . . . .

V.V. Abramov, V.D. Yenalyev, M.S. Akutin, N.M. Tchalya, V.I. Melnichenko, and

A.N. Shelest

Initiated Styrene Copolymerization with Polybutadiene Reaction Conditions on the Length of Polystyrene Graft Branches .............

V.D. Yenalyev, N.A. Noskova, and O.P. Shmelyova

On the Influence of the Initial Stages of Styrene Copolymerization with Polybutadiene on High Impact Polystyrene Morphology . . . . . . .

V.D. Yenalyev, N.A. Noskova, V.I. Melnichenko, O.P. Bovkunenko, and V.M. Bulatova

Characterization of Polymer Blends, Block Copolymers, and Graft Copolymers by Fractionation Procedures using Demixing Solvents . . . . . . .

R. Kuhn 
A Critical Assessment of the Application of FT-IR Spectroscopy to the Study of Crystalline/

Compatible Polymer Blends . . . . . . . . . .

M.M. Coleman, D.F. Varne11, and J.P. Runt

Fracture Toughness of Poly(Methyl Methracrylate)

Blends . . . . . . . . . . . . . . .

R.P. Kusy and W.F. Simmons

Melt Rheology of Blends of Semi-Crystalline Polymers:

Part II, Dynamic Properties of Poly(Ethylene

Terephtalate) - Poly(Amide - 6,6)

Molten Blends . . . . . . . . . . . . .

L.A. Utracki and G.L. Bata

Domain Stability During Capillary Flow of Well

Dispersed Two Phase Polymer Blends: Polystyrene/

Polymethylmethacrylate Blends . . . . . . . . .

J. Lyngaae-Jorgensen, F.E. Andersen, and N. Alle

Melt Compounding of PVC with Ethylene Copolymer

Resins . . . . . . . . . . . . . . . .

G.H. Hofmann

Polymer-Performance on the Dimensional Stability and the Mechanical Properties of Wood-Polymer

Composites Prepared by an Electron Beam

Accelerator . . . . . . . . . . . . . . .

T. Handa, I. Seo, T. Ishii, and Y. Hashizume

Phase Domain Size and Continuity in Sequential

IPN's: A Review .................

L.H. Sperling, J.M. Widmaier, J.K. Yeo, and J. Michel

RIM Systems from Interpenetrating Polymer Networks . . •

R. Pernice, K.C. Frisch, and R. Navare

Microphase Segregation in Segmented Amine-Cured

Polyurethanes . . . . . . . . . . . . . .

C.R. Desper and N.S. Schneider

Synthesis and Properties of Some Copolymers of

Maleic Anhydride Derivatives . . . . . . . .

C. Schneider and J. Wolff 
Photothermal Degradation of Ethylene/Vinylacetate Copolymer . . . . . . . . . . . . . . 267 R.H. Liang, S. Chung, A. Clayton, S. Di Stefano, K. Oda, S.D. Hong, and A. Gupta

Syntheses of Nitrogenous Materials by RF Plasmas . . . . 279 T.L. Ward, O. Hinojosa, and R.R. Benerito



